\title{
Investigation of Climatological Components on Runoff Modeling using SWAT
}

\author{
${ }^{1}$ Kaveh Ostad-Ali-Askari, ${ }^{2}$ Sayed-Reza Alvankar and ${ }^{3}$ Hamid-Reza Rabiefar \\ ${ }^{I}$ Department of Water Engineering, College of Agriculture, Isfahan University of Technology, Isfahan, Iran \\ ${ }^{2}$ Ballard Power Systems and BC Hydro Co., Hydro-Technical Engineering Consultant Company, \\ Greater Vancouver Metropolitan Area, Vancouver, British Columbia, Canada \\ ${ }^{3}$ Department of Civil Engineering, South Tehran Branch, Islamic Azad University, Tehran, Iran
}

Article history

Received: 18-07-2020

Revised: 28-11-2020

Accepted: 30-12-2020

Corresponding Author:

Kaveh Ostad-Ali-Askari

Department of Water

Engineering, College of

Agriculture, Isfahan University

of Technology, Isfahan 84156-

83111, Iran

Email: kaveh.oaa2000@gmail.com ostadaliaskari.k@of.iut.ac.ir

\begin{abstract}
It was planned most hydraulic projects, for instance barriers, it was defined the overflow of the rivers. If the river absences any position to measure the yield, the hydraulic models can be utilized to estimate it. SWAT is widely-used computerized mockups. It was required to feed such influential climatological information as precipitation, temperature, wind speed, solar radiation and relative humidity, in addition to, watershed information with the curve number and roughness constant to compute the watershed runoff. Watershed contain few climate positions and it was dangerous that the registered data in a position was not characterized the entire watershed. Consequently, the amount of the runoff estimation fault wants to be defined. This research considers the sensitivity of the runoff estimation for rivers, Using the SWAT prototypical, based on differences in such climatological components as precipitation, solar radiation, wind, humidity and temperature. The obtained consequences specify that with a $30.46 \%$ decline in the average monthly precipitation, sunshine, relative humidity, wind and temperature, it was set ermined $64.73 \%$ decline, $115.14 \%$ rise, $45.99 \%$ reduce, $126.58 \%$ rise and $40.15 \%$ rise in modeled runoff, individually. The wind speed and the solar radiation are the most sensitive and temperature is the least sensitive parameters in the runoff estimation.
\end{abstract}

Keywords: Meteorological Parameters, Rainfall Runoff, Sensitivity Analysis, SWAT, Watershed Yield

\section{Introduction}

So as to shape a dam, it was essential to determine the monthly and annular yields of the river to calculate the volume and the height of the dam. A device position cans quantity the input water of the dam. In the nonappearance of the device place, a computerized model, for instance SWAT model, was be applied to evaluate the stream and the input runoff. The computerized models can perform precise and complicated calculations in a short time. In order to calculate the watershed runoff on the one hand, the model requires such influential climatological information as precipitation, temperature, wind speed, solar radiation and relative humidity and on the other hand we need the watershed basin information including the curve number and the roughness coefficient. Owing to the limitation in the quantity of climate positions in watershed basins, the standards registered in a position do not signify the entire watershed (Ghane et al., 2017a). There is a requirement to compute the runoff estimation fault. This research is depending on SWAT model, objects to examine the sensitivity of the river runoff estimation to differences in the most prominent climatological components including precipitation, solar radiation, wind, humidity and temperature. The improvement of a nation is straight connected to the energy invention. Inappropriately, Iran is fronting disastrous dynamism catastrophe at current period. The elementary and inexpensive basis of control manufacture is hydropower in Iran owing to the attendance of usual landscape which makes ordinary hydraulic heads lengthwise watercourses particularly in mountainous zones (Ghane et al., 2017b). The water issue in north Iran is severe. Agronomy water feeding is very great that directed to a solemn descent in water table. 
Consequently, investigation on actual water equivalent in the area is very significant. The revision enhanced swat prototypical and used it on the region level actual water equivalent reproduction: Usage the enhanced SWAT prototypical, by climatological information and distant detecting Evapotranspiration (ET), the Talar dispersed model is advanced depend on the soil plan, water Conservancy and terrestrial usage from the distant detecting of Talar county, Mazandaran province. Harvest design alteration, irrigation arrangement alteration and irrigation aquatic basis alteration circumstances is pretend and actual water equivalent of dissimilar situations is examined. The consequence of the investigation can suggest situation to the agronomy for actual water equivalent organization. Great agronomic water feeding caused in greatly lower groundwater stage. Consequently, investigation on agronomic physical Water-equivalent has a significant theoretical consequence. Engineering water-equivalent, mostly accepted in modern agronomic water-equivalent, can decrease the evaporation and improve the draining efficiency. However prolonging irrigation zone and cumulative irrigation occurrence will consume more water possessions owing to the intensification of ET, which will reason severe significances for example deteriorating of water scarcity, severe decline of unnecessary groundwater corruption, devastation of environmental situation, amazing effect on downstream water usage and unmaintainable usage of water possessions in zones deficient of water. So, in the Talar basin, a zone missing of water possessions, we must, on the evidence of cumulative harvest and equivalent water, perform a novel agronomic water-equivalent style with the determination of decreasing ET, which comprises regulating agronomic construction, enhancing irrigation technique and accepting agronomic organization events and a dispersed water series prototypical is essential while creating and assessing organization events. SWAT is a extensively applied complete dispersed prototypical of water possessions and situation. SWAT prototypical is mostly applied to pretend and estimate diverse organization procedures and effect on water possessions source produced by weather alteration and assess contamination in the washbasin. But, since sub basin separation is depend on DEM instinctive abstraction; usage of SWAT will encounter prodigious problems in basic zones, particularly zones with severe anthropological disruption. Conferring to the fault of SWAT prototypical presence depend on DEM instinctive partition of subbasins in natural zones and in view of that Iran's water possessions existence accomplished on the foundation of managerial separation, depend on SWAT basis program, we has advanced a novel SWAT border, enhanced the technique by which SWAT prototypical shares the subbasins, allowable the operators to do anthropological-processor interrelated hydrological component illustration conferring to considering superficial evidence in the investigation zone, built SWAT prototypical conferring to the hydraulic association amongst the hydrological components and supported the arithmetical examination purposes of SWAT prototypical, through which the numerical examination of hydrological aspects can be done depend on together ordinary hydrological components and managerial separation. Fundamental superficial evidence in the investigational zone, comprising DEM, terrestrial usage and soil, ought to be lengthily measured while separating sub basins. Anthropological features for example water engineering in the element region ought to be considered since water engineering is greatest possible to alteration the divergence condition in the element region. Afterward the separation of sub basins, the water engineering association amongst sub basins ought to be defined, which requisite a complete deliberation of DEM, soil, land usage and water engineering in the point region for the consequence correctness will affect the pretend consequence prepared by SWAT prototypical. Collecting the hydraulic forms is required afterward the purpose of water engineering association. The information ought to be contribution into the prototypical to distribute sub basins and make connected component collections (Ghane et al., 2015).

\section{Literature}

It was considered SWAT to study the deposit and the sewage of nutrients in the east of Gorganrood watershed. The same model has been applied and confirmed from 1999 to 2006. Data from 2007 to 2010 was applied to examining the precision and in the both stages of verification and validation the results were suitable. The SWAT model keeps the ability to make various scenarios to study different managerial issues (Chu and Shirmohammadi, 2004). It was applied SWAT to excite the average monthly discharge of Emameh watershed. The obtained consequences indicated a advanced compassion of the prototypical to the over land coarseness constant (Gholami, 2003).

Saadati (2003) dealt with the stimulation of the daily discharge, water balance and land application in Talar watershed. The results provided by the model were sensitive to the period, that is, the yearly and the monthly stages produced more rational consequences in contrast with the everyday. It was utilized the SWAT prototypical to assess the discharge and approved the efficacy of the model. Omani et al. (2007) employed the above model in modeling Ghareh-sar watershed and decided that the SWAT prototypical is a accomplished tool for interesting hydrologic mechanisms (Omani et al., 2007). 
Rostamian et al. (2006) stimulated the runoff in Behestabad watershed and decided that the SWAT prototypical is not capable of stimulate the maximum currents.

It was used SWAT in Emameh and claimed that the above model was efficient in the runoff estimation.

It was applied SWAT to assess the over land current in a 33.4 square kilometers watershed situated in Maryland. The obtained consequences proved that the estimations made by the SWAT model were not so accurate during very wet years. By omission of the wet year, the monthly estimations of the over land current runoff were more accurate (Mwendera and Feyen, 1992).

It was decided that the estimations of runoff made by SWAT agree with the amounts measured in Lershi watershed. Schuol et al. (2008) claimed that SWAT is highly capable in making realistic stimulations of hydrological balance.

It was applied SWAT to stimulate the discharge of the current in Bask river watershed and the model was proved to be satisfactory in forecasting the current (Santhi et al., 2001).

\section{Materials}

The case to be studied was restricted to Talar watershed including Sangdeh, Darzikela, Sootkela, Valikchal and Valikbon towns. The zone of Talar watershed is almost 67.74 square kilometers and the foremost stream gives for 18.9 kilometers. The topographical organizes of the rivers are as follows: Latitude from $36^{\circ}-07^{\prime}$ to $36^{\circ}-15^{\prime} \mathrm{N}$ and longitude from $53^{\circ}-14^{\prime}$ to $53^{\circ}-29^{\prime} \mathrm{E}$. There is a measurment position on Talar River at Valikbon. The position, constructed in 1969 , is situated at longitude of $53^{\circ}-20^{\prime}$ and the latitude $36^{\circ}-19^{\prime}$ to quantity it's Discharge. Figure 1 displays the position of Talar watershed (Lei et al., 2015).
This model takes the precipitation, temperature, solar radiation, wind speed and relative humidity data accessible from January 1979 till January 1990 into account to stimulate the runoff. The mentioned numerical components were repossessed from Pol-e-sefid cineoptic, Sangdeh and Darzikela climatology, Valikchal precipitation-gauge and Valik hydrometer positions (Ghane et al., 2018).

\section{Introducing SWAT}

SWAT was advanced by the agriculture ministry of the US and the agriculture research service of Grassland water and soil investigation workshop in Texas. This prototypical stimulates the stream release and to this end such climatical information as precipitation, temperature, solar radiation, wind speed and relative humidity are required. This software needs as a minimum the temperature and precipitation data and is able to stimulate the other items. It similarly requires land map and the numerical elevation prototypical. Arc GIS software performs the SWAT prototypical (Akram et al., 2018).

\section{Formulas and Tables}

The number of SCS curve is a purpose of soil penetrability, terrestrial application and the humidity already retained in the soil. Different types of curve number were considered for humidity condition II in various kinds of terrestrial from 65 to 79 based on the SWAT methods tables and the best quantity for the district was gained as 69 .

SCS runoff equation is an empirical model developed in 1950 after 20 years of studying the relationship between rain and runoff in the small American villages' watersheds. The model estimates the runoff in various land applications and different types of soil (Rallison and Miller, 1982).

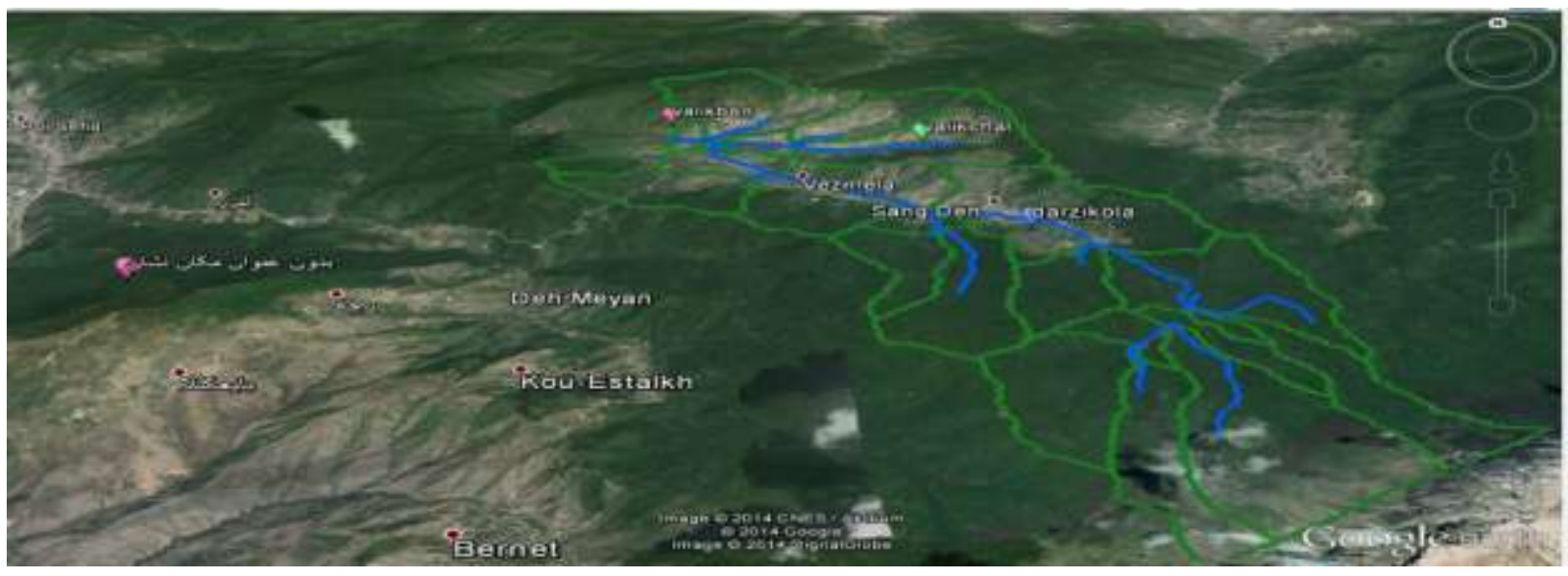

Fig. 1: Show the position of Talar Watershed until Valik hydrometer Position 
Equation 1 shows the curve number as follows:

$Q_{\text {surf }}=\frac{\left(R_{\text {day }}-I_{a}\right)^{2}}{\left(R_{\text {day }}-I_{a}+s\right)}$

where, $Q_{\text {surf }}$ is the collected overflow or the additional of precipitation $(\mathrm{mm}), R_{\text {day }}$ is the height of water per day $(\mathrm{mm}), I_{a}$ is the original leakage of the superficial replacement, the dispersion before runoff $(\mathrm{mm})$ and $S$ is the water saving $(\mathrm{mm})$. A change in saving parameter ends in changes in the type of the soil, land application, organization, gradient and soil content. Saving parameter is measured in Eq. 2:

$s=25.4\left(\frac{1000}{C N}-10\right)$

where, $C N$ is the Curve Number for day. $I_{a}$ is about assessed as 0.25 and fed to Eq. 1 to obtain Eq. 3:

$Q_{\text {surf }}=\frac{\left(R_{d a y}-0.2 s\right)^{2}}{\left(R_{d a y}+0.8 s\right)}$

Runoff occurs only if $R_{d a v} \succ I_{a}$. The graphic explanations for Eq.3 with the arithmetical standards of diverse curves are existed in Fig. 2. For example apparent in Fig. 2, the developed the quantity of the curve, the supplementary precipitation runoff. The runoff ensuing from precipitation varies in a curve consistent with the Curve Number (Hao et al., 2004).
SCS curve describes three humidity situations: 1-dry 2-Medium humidity 3-wet. The humidity state 1 (dry) keeps the bottommost rate in the regular curve number. The curve numbers for humidity situations 1 and 2 are designed depend on Eq. 4 and 5:

$$
C N_{1}=C N_{2}-\frac{20 \cdot\left(100-C N_{2}\right)}{\left(100-C N_{2}+\exp \left[2.533-0.0636\left(100-C N_{2}\right)\right]\right)}
$$

$C N_{3}=C N_{2} \cdot \exp \left[0.00673 \cdot\left(100-C N_{2}\right)\right]$

where, $C N_{1}, C N_{2}$ and $C N_{3}$ are the number of curves 1,2 and 3 of previous humidity, respectively.

Developed the equation of curve numbers for diverse gradients as Eq. 6:

$C N_{2 s}=\frac{\left(\mathrm{CN}_{3}-\mathrm{CN}_{2}\right)}{3} \cdot[1-2 \cdot \exp (-13.86 \cdot s l p)]+C N_{2}$

where, $C N_{2 s}$ (the number of previous humidity II) is set for the slope, $\mathrm{CN}_{3}$ (the curve number III) is a $5 \%$ gradient, $\mathrm{CN}_{2}$ (the number of previous humidity II) is for a $5 \%$ gradient and SLP is the usual gradient of sub-basins. SWAT does not establish the curve numbers for the gradient. Situation is completed before ingoing the curve number and over the input file organization. SWAT input flexibles, using the curve number technique, marks the overland runoff design as in Table 1.

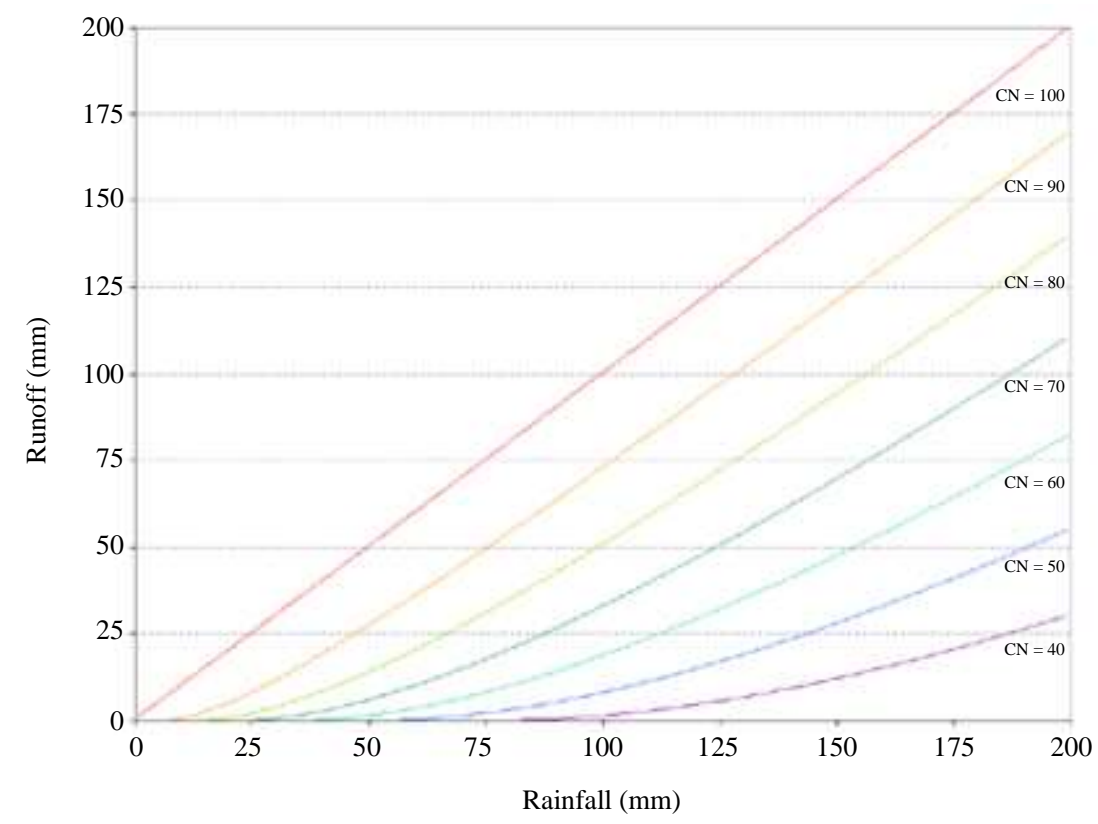

Fig. 2: Relationship of runoff to rainfall in SCS Curve number method 
Table 1: SWAT input variables that pertain to surface runoff calculated with the SCS curve number method

\begin{tabular}{|c|c|c|}
\hline Various name & Description & Input file \\
\hline IEVENT & Rainfall, runoff, routing option. &.$b s n$ \\
\hline ICN & $\begin{array}{l}\text { Regular curve number design technique: } 0 \text { compute regular } \mathrm{CN} \text { rate as a purpose of } \\
\text { soil moisture, } 1 \text { computer daily } \mathrm{CN} \text { rate as a purpose of vegetable evapotranspiration }\end{array}$ &.$b s n$ \\
\hline CNCOEF & $\begin{array}{l}\text { Cncoef: Weihghting quantity applied to compute the preservation constant for daily } \\
\text { curve quantity designs reliant on vegetable evapotranspiration }\end{array}$ & .bsn \\
\hline PERCIPITATION & $\mathrm{R}_{\text {day: }}$ Daily precipitation $\left(\mathrm{mm} \mathrm{H}_{2} \mathrm{O}\right)$ & .pcp \\
\hline $\mathrm{CN}_{2}$ & $\mathrm{CN}_{2}$ : Humidity state II curve number & .mgt \\
\hline CNOP & $\mathrm{CN}_{2}$ : Humidity state II curve number & .mgt \\
\hline
\end{tabular}

Manning over land roughness constant value for the planned watershed district and connected SWAT tables are in the assortment of 0.05 to 0.2 . The finest rate for this district was designed as 1 .

The land current concentration time $t_{o v}$ is calculated as Eq. 7:

$$
t_{o v}=\frac{L_{s l p}}{3600 \cdot v_{o v}}
$$

where, $L_{s l p}$ is the distance of sub-basin gradient, $v_{o v}$ is the rapidity of land current $(\mathrm{m} / \mathrm{s})$ and 3600 is the component alteration component. The speed of the land current was assessed depend on Eq. 8 or manning equation:

$v_{o v}=\frac{q^{0.4} o v^{s l p^{0.8}}}{n^{0.6}}$

where, $q_{o v}$ is the regular of the terrestrial existing, slp is the mean gradient of sub-basin and $n$ is the Manning roughness quantity for the sub-basin. The degree of stream is presumed as $6.35 \mathrm{~mm} / \mathrm{h}$ and component alteration was completed over Eq. 9 and 10:

$$
\begin{aligned}
& v_{o v}=\frac{0.005 \cdot L_{s l p}^{0.4} \cdot s l p^{0.8}}{n^{0.6}} \\
& t_{o v}=\frac{L_{s l p}^{0.6} \cdot n^{0.6}}{18 \cdot s l p^{0.8}}
\end{aligned}
$$

anning formula to:

$$
\begin{aligned}
& v=D^{2 / 3} S^{1 / 2} n^{-1} \\
& q=D v \\
& q=D^{5 / 3} S^{1 / 2} n^{-1} \\
& n=D^{5 / 3} S^{1 / 2} q^{-1}
\end{aligned}
$$

Anywhere $v=$ the mean flow rapidity $\left(\mathrm{m} \mathrm{s}^{-1}\right), n=$ the Manning resistance coefficient and $S=$ the angle gradient $\left(\mathrm{m} \mathrm{m}^{-1}\right)($ Mwendera and Feyen, 1992).

\section{Soil Category}

In this research, we deal with the optimal Curve Number and Overland Roughness constant of watershed. The precipitation information was selected from the diverse climatological parameters to gain the optimal Curve Number and the Overland Roughness factor of the watershed. SWAT was originally perform with the curve number $C_{2}=66$ and the Overland Roughness factor 0.15. The results are presented in Fig. 3 (Ostad-Ali-Askari et al., 2020).

To improve components diverse standards for the Curve Number and roughness factor were applied and the relationship of the Discharge variations with individually one of parameters presented in Table 2 and 3 are denoted in a Fig. 4 to 7. In comparison with runoff quantities recorded in hydrometer position and the planned quantity of current, the finest Curve Number was 67 and the Roughness factor of watershed was 0.1 . Next, depend on the obtained values, differences in SWAT input components were applied to simulate the river runoff (Soil Conservation Service. 1972). The effects of difference in individually of climatological components on runoff was planned and contrasted with the experimental runoff. It would be stated that in this phase of designs individual precipitation information were fed into the prototypical (US Department of Agriculture. 1986).

\section{Sensitivity Analysis of Meteorological Parameters in River Runoff}

In this stage of research, other essential climatological components with temperature, relative humidity, wind speed and solar radiation as well as precipitation were fed to SWAT and the average runoff, as is shown in the third row if the Table 4, was designed as 0.5752 cubic meters per second.

\section{Precipitation Effect}

So as to study the sensitivity of the runoff assessed by the prototypical to precipitation, originally, all precipitation standards were multiplied to 1.6 and the runoff was designed. The factual quantity of precipitation was applied to gain the regular lasting runoff of the river (0.5704233). With a $53 \%$ increase in the precipitation, the river runoff was enlarged to 1.285224082 (a 133\% increase). 
$2 / 5$

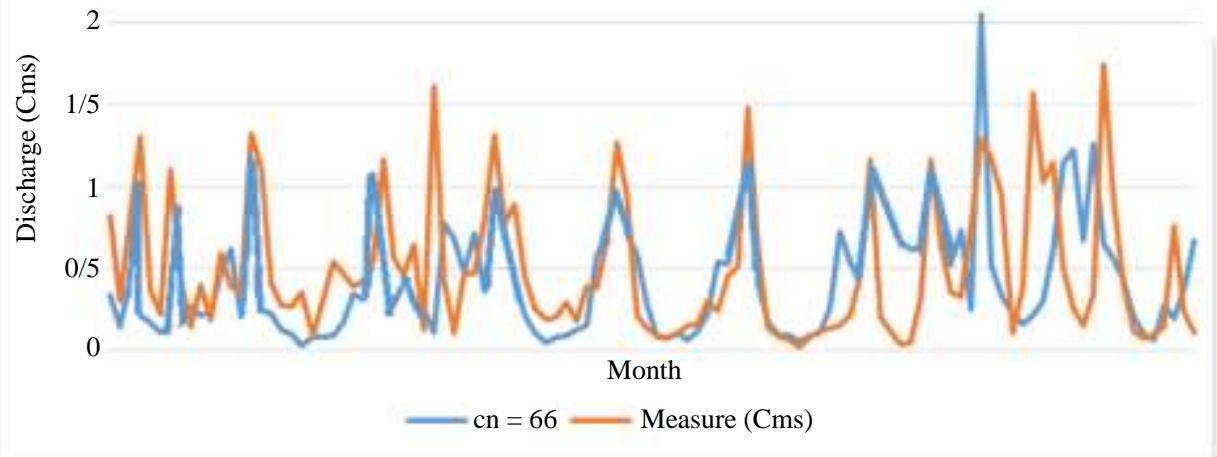

Fig. 3: Compare monthly simulated discharge of the SWAT with measured discharge

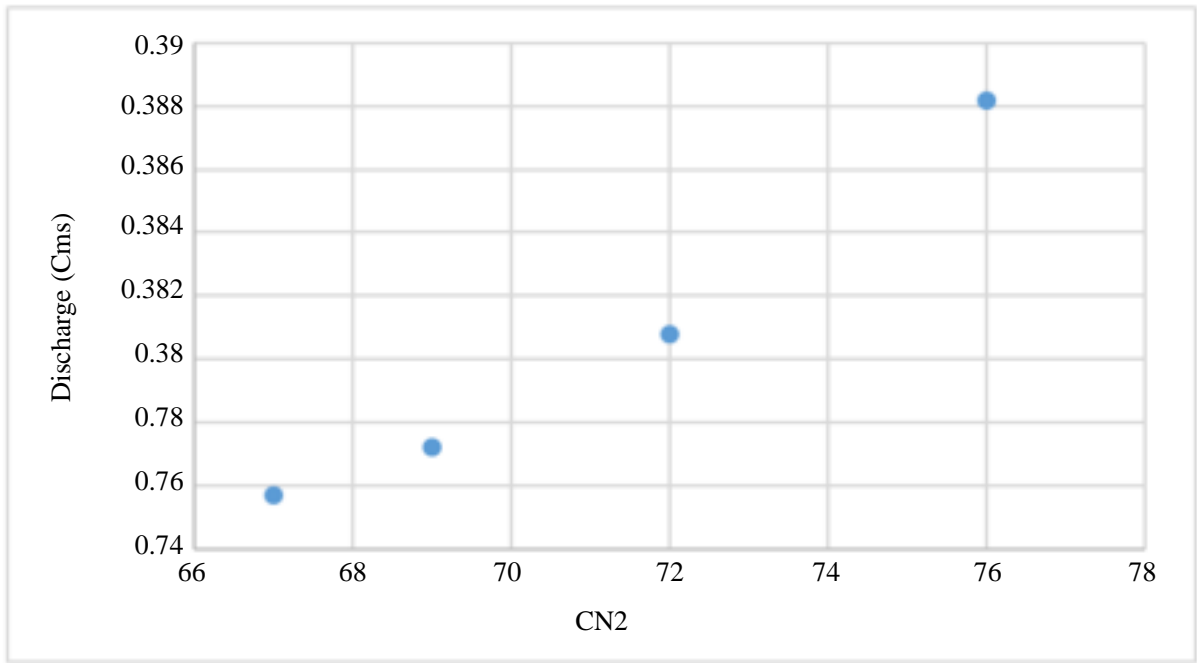

Fig. 4: Difference CN2 with simulated discharge

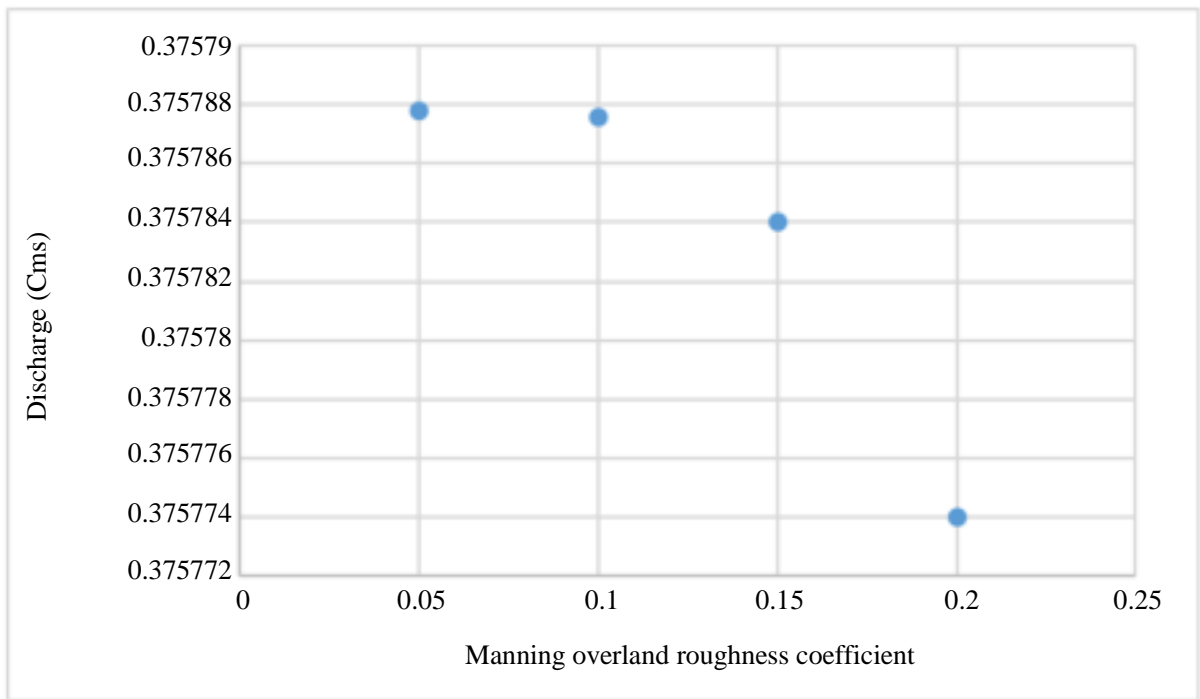

Fig. 5: Variance manning overland roughness factor with simulated discharge 


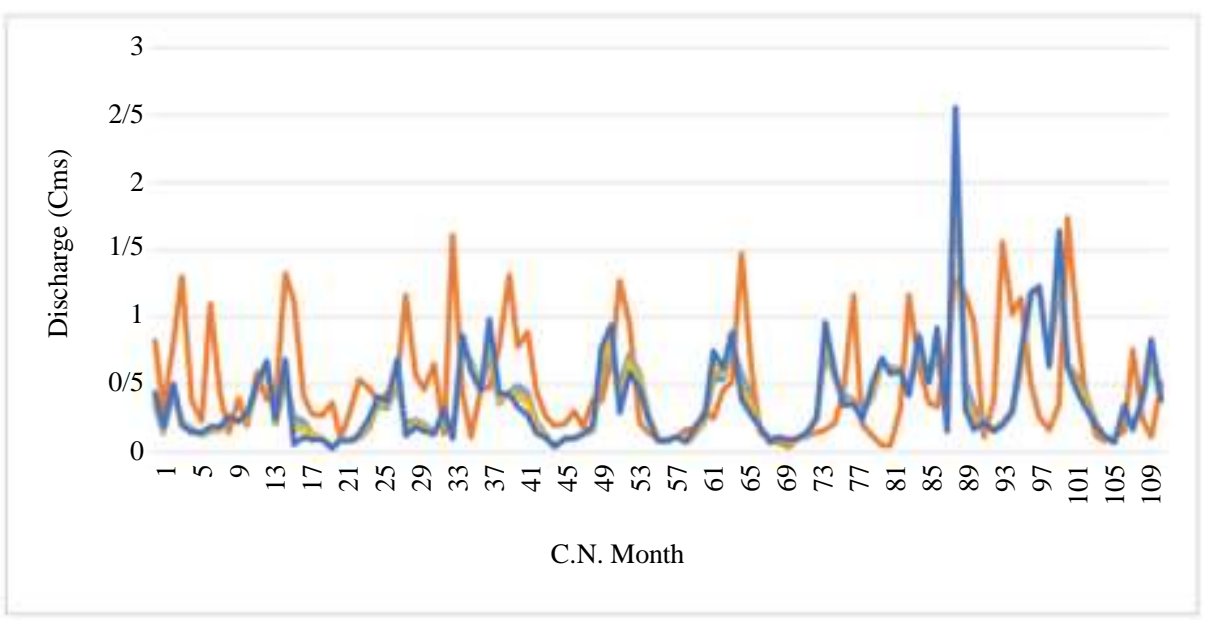

Fig. 6: Simulated discharge stream with variable $\mathrm{CN}$ to compare measured discharge

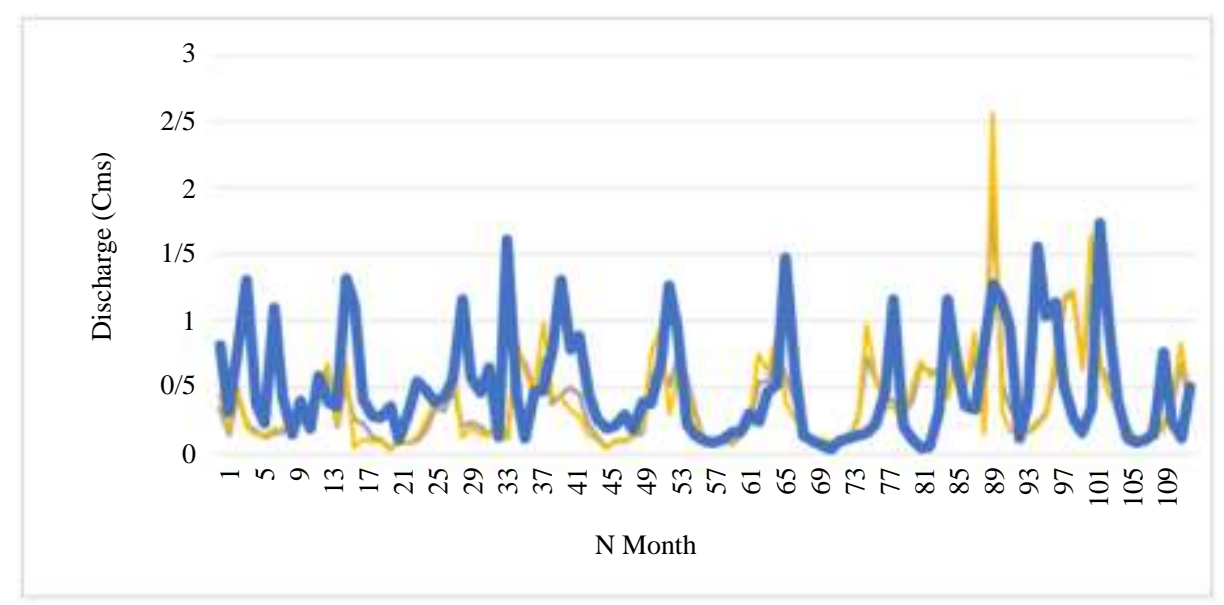

Fig. 7: Simulated discharge river with variable manning overland roughness factor to compare maesured discharge

Table 2: Examine effective $\mathrm{CN}$ in the average simulated discharge

\begin{tabular}{lllll}
\hline $\mathrm{CN}$ & 66 & 70 & 73 & 77 \\
\hline Average simulated discharge & 0.376987 & 0.377344 & 0.38055 & 0.388605 \\
Average measured discharge $\left(\mathrm{m}^{3} / \mathrm{s}\right)$ & 0.498976 & 0.498976 & 0.498976 & 0.498976 \\
Error $\left(\mathrm{m}^{3} / \mathrm{s}\right)$ & 0.121989 & 0.121632 & 0.118426 & 0.11075 \\
Percent change or variable & 0 & $0.3999 \%$ & $1.3601 \%$ & $3.3283 \%$ \\
\hline
\end{tabular}

Table 3: Examine effective over land roughness coefficient in the average discharge calculation

\begin{tabular}{|c|c|c|c|c|}
\hline Manning overland roughness coefficient & 0.1 & 0.15 & 0.17 & 0.23 \\
\hline Average simulated discharge $\left(\mathrm{m}^{3} / \mathrm{s}\right)$ & 0.375814 & 0.375814 & 0.375814 & 0.375814 \\
\hline Average measured discharge $\left(\mathrm{m}^{3} / \mathrm{s}\right)$ & 0.498972 & 0.498972 & 0.498972 & 0.498972 \\
\hline $\begin{array}{l}\text { Difference average measured discharge } \\
\text { and simulated discharge }\left(\mathrm{m}^{3} / \mathrm{s}\right)\end{array}$ & 0.123170 & 0.123170 & 0.123182 & 0.123182 \\
\hline Percent change or variable & 0 & 0 & $-0.0043 \%$ & $-0.0009 \%$ \\
\hline
\end{tabular}

Table 4: result variable simulated discharge that change preiciptation

\begin{tabular}{lllll}
\hline & $\begin{array}{l}\text { Average simulated } \\
\text { discharge }\left(\mathrm{m}^{3} / \mathrm{s}\right)\end{array}$ & $\begin{array}{l}\text { Average measured } \\
\text { discharge }\left(\mathrm{m}^{3} / \mathrm{s}\right)\end{array}$ & $\begin{array}{l}\text { Difference average } \\
\text { maesured discharge and } \\
\text { simulated discharge }\left(\mathrm{m}^{3} / \mathrm{s}\right)\end{array}$ & $\begin{array}{l}\text { Percent variable } \\
\text { simulated discharge }\end{array}$ \\
\hline $\mathrm{PCP} \times 1.5=3.11193$ & 1.285224082 & 0.49895316 & 0.7866 & $126.21 \%$ \\
$\mathrm{PCP} \times 0.7=1.452184$ & 0.203898444 & 0.49895316 & 0.2959 & $-65.07 \%$ \\
$\mathrm{PCP}=2.07462$ & 0.5704314 & 0.49895316 & 0.0719 & 0 \\
\hline
\end{tabular}


With a $33 \%$ decline in precipitation, the average runoff reduced for $65.3 \%$ (0.203889459 cubic meters per second). Accordingly, we face 0.7153 rise and 0.3676 decline in monthly runoff. As apparent in Fig. 8, the monthly runoff route is rising depend on the precipitation. With a 53\% rise and a $32 \%$ decline in input precipitation, the inspired runoff will be 0.82 and 0.31 which are higher and lower than the average observed monthly runoff, individually.

\section{Solar Radiation}

Effect with a $22 \%$ rise and a $33 \%$ decline in the input solar radiation, the simulated runoff diversed from 0.59 cubic meters per second to 0.60 and 1.24 cubic meters per second, individually. The monthly differences are considered in Table 5 and Fig. 10 and 11 with a 22\% rise and a 33\% decline in the input solar radiation, the simulated runoff would increase 0.12 and 0.77 cubic meters per second respectively.

Figure 9 shows variance simulated discharge with alteration data input precipitation. The trend is increased suddenly.

\section{Humidity Effect}

By a $20 \%$ intensification and a $30 \%$ decline in the input relative humidity, the average monthly runoff would change from 0.5704 to 0.6947 and 0.3084 , individually. These $21.79 \%$ rise and $45 \%$ decline are determined in the Table 6 and Fig. 12 and 13. With a $20 \%$ rise and $30 \%$ decline in input relative humidity, the simulated runoff was $39.25 \%$ higher and $38.18 \%$ lesser than average measured monthly runoff, individually.

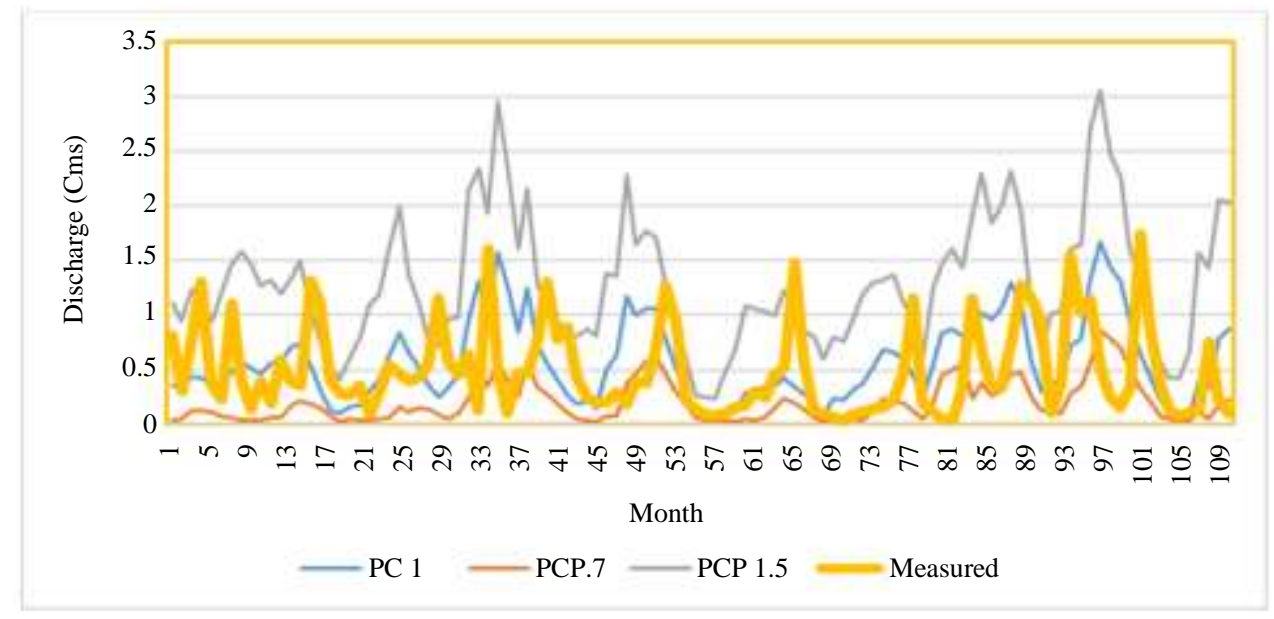

Fig. 8: Result simulated discharge with change precipitation

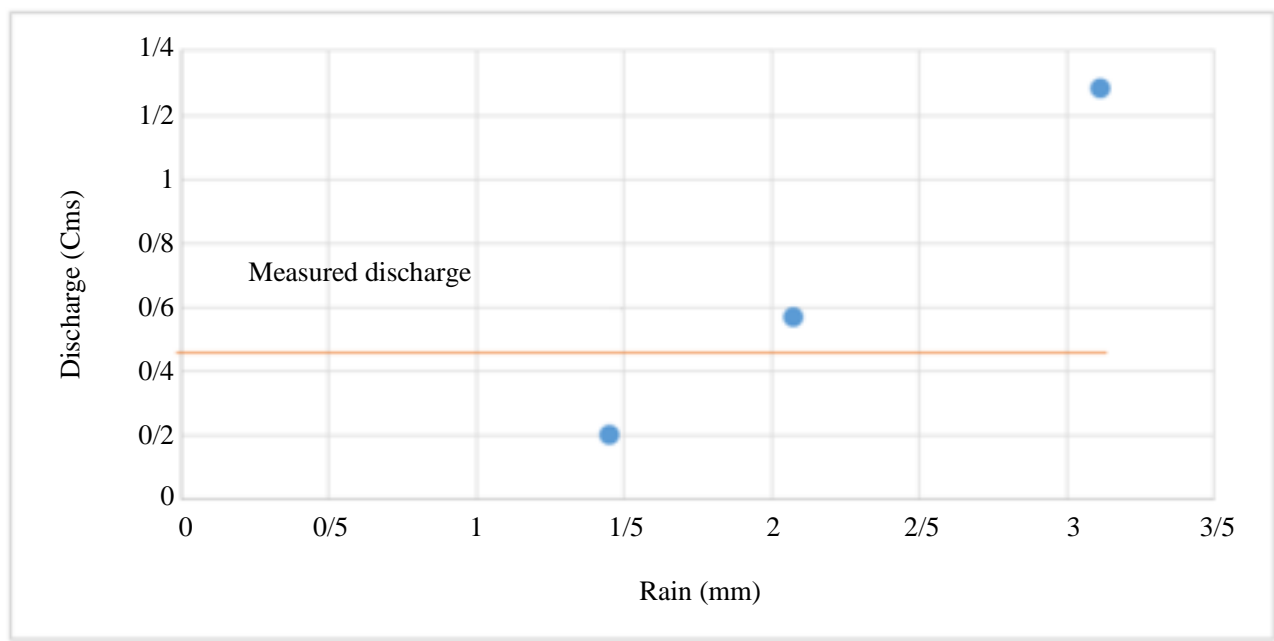

Fig. 9: Difference simulated discharge with change information input precipitation 


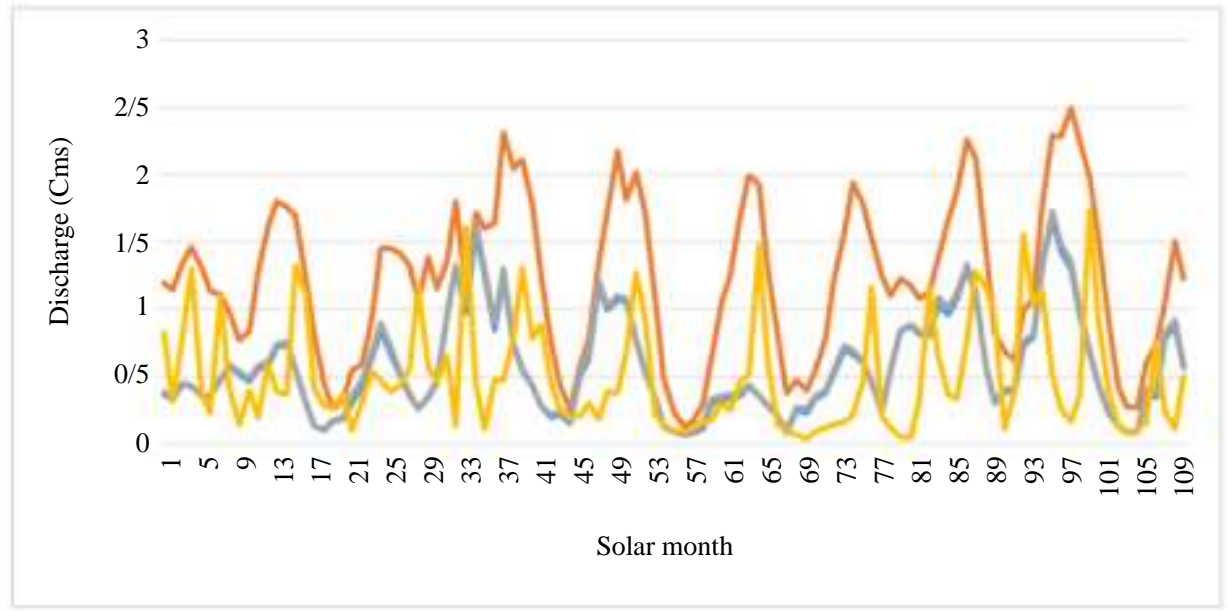

Fig. 10: Result simulated discharge with Difference information input Solar Radiation

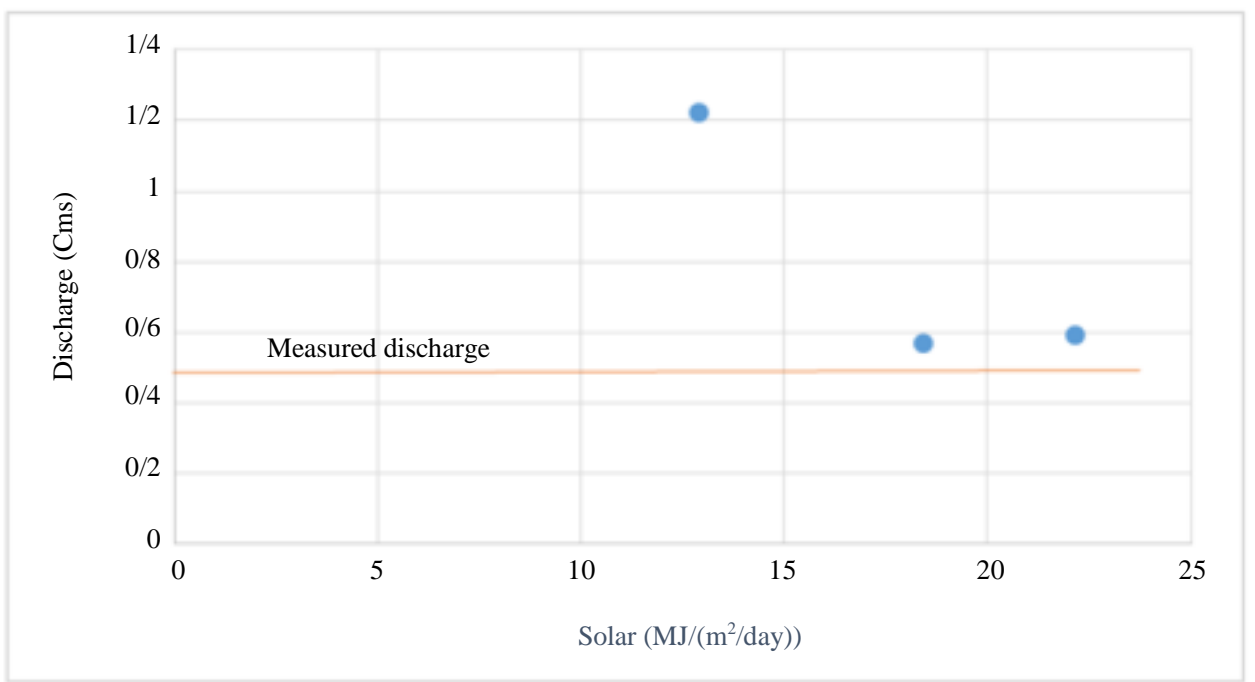

Fig. 11: Simulated discharge average monthly with difference information solar radiation

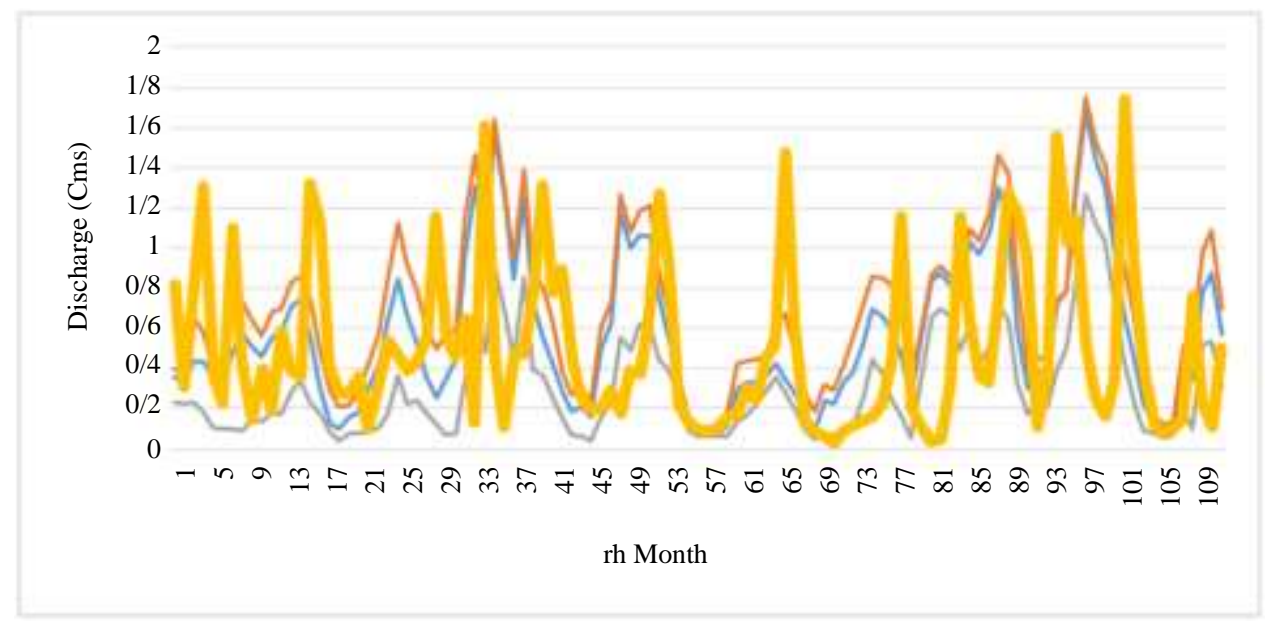

Fig. 12: Result simulated discharge average monthly with difference information input relative Humidity 


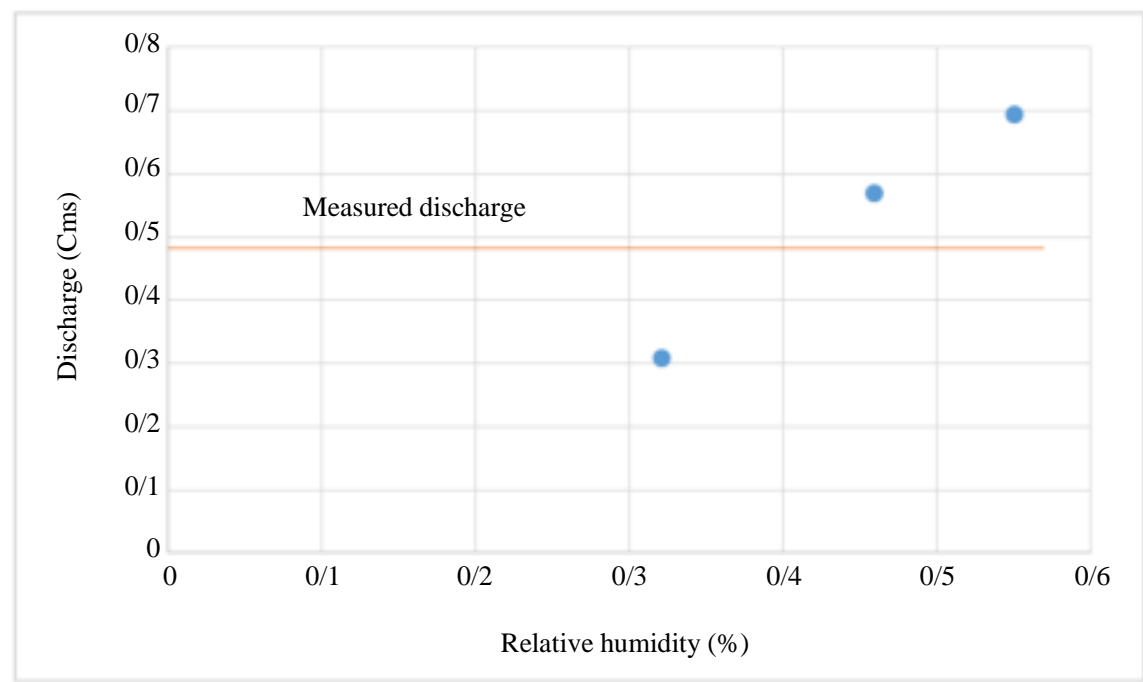

Fig. 13: Simulated discharge with difference information input humidity

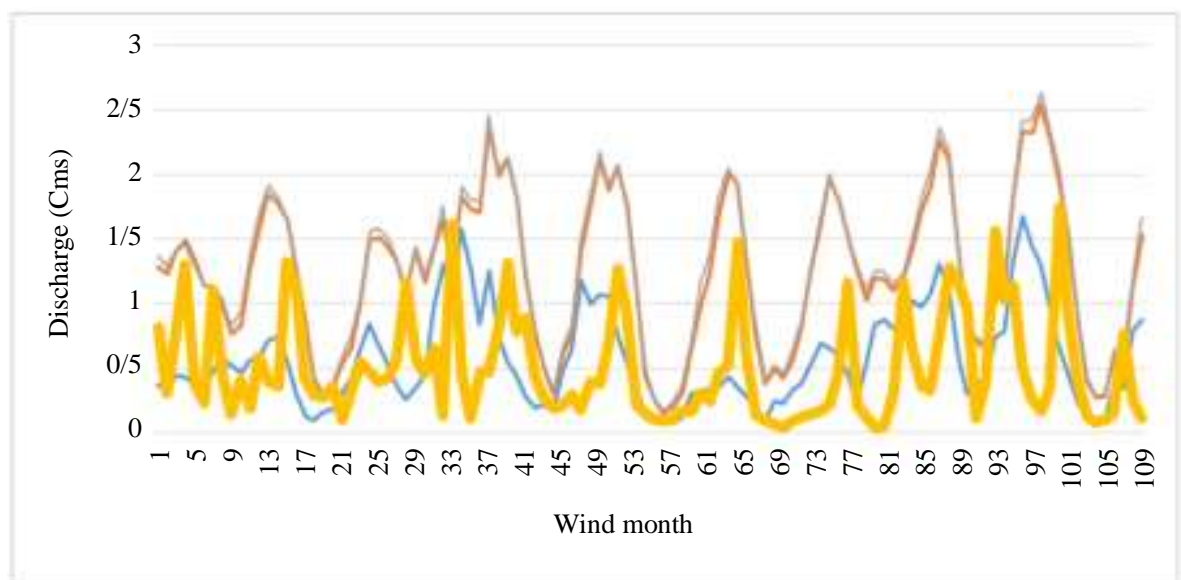

Fig. 14: Simulated discharge with difference information input wind speed

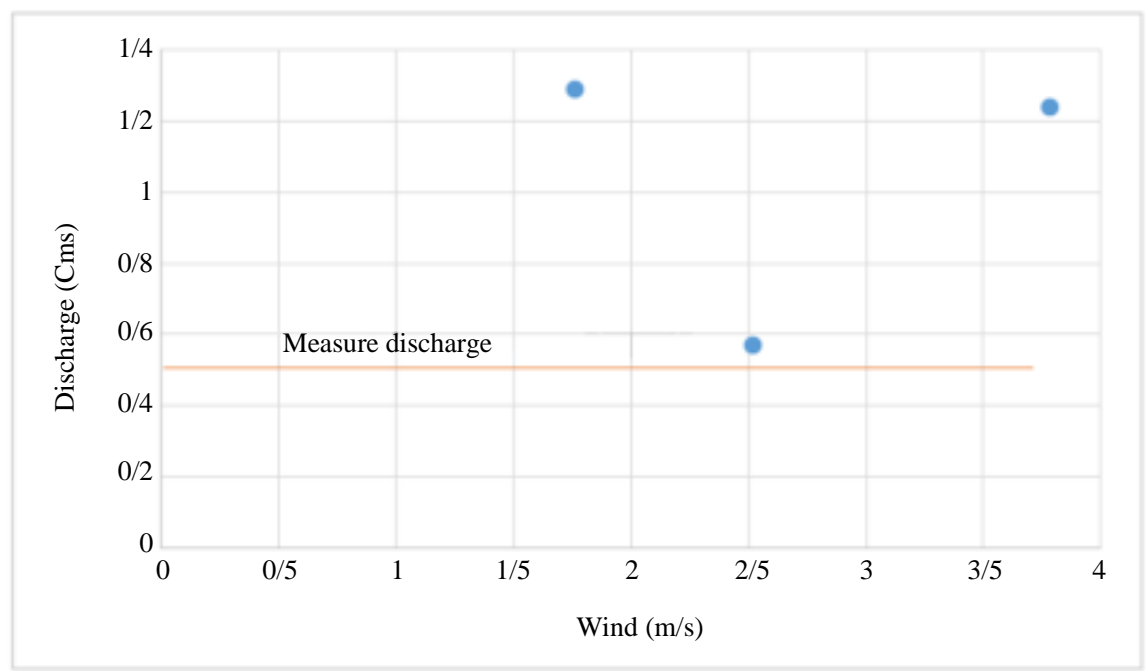

Fig. 15: Simulated discharge with difference information input wind speed 
Table 5: Difference simulated discharge of the model SWAT with difference information input solar radiation

\begin{tabular}{lllll}
\hline $\begin{array}{l}\text { Average solar radiation } \\
\left(\mathrm{MJ} /\left(\mathrm{m}^{\wedge} 2 / \text { Day }\right)\right)\end{array}$ & $\begin{array}{l}\text { Average simulated } \\
\text { discharge }\left(\mathrm{m}^{3} / \mathrm{s}\right)\end{array}$ & $\begin{array}{l}\text { Average measured } \\
\text { discharge }\left(\mathrm{m}^{3} / \mathrm{s}\right)\end{array}$ & $\begin{array}{l}\text { Difference average } \\
\text { measured discharge and } \\
\text { simulated discharge }\left(\mathrm{m}^{3} / \mathrm{s}\right)\end{array}$ & $\begin{array}{l}\text { Percent variable } \\
\text { simulated discharge }\end{array}$ \\
\hline Solar $\times 1.22=22.19$ & 0.59279278 & 0.498653719 & 0.0943 & $3.91236 \%$ \\
Solar $+1.73=12.92$ & 1.224635 & 0.498653719 & 0.7267 & $114.75 \%$ \\
Solar $=18.45$ & 0.5704326 & 0.498653719 & 0.0723 & 0 \\
\hline
\end{tabular}

Table 6: Difference simulated discharge with changing information input humidity

\begin{tabular}{lllll}
\hline $\begin{array}{l}\text { Average } \\
\text { humidity }(\%)\end{array}$ & $\begin{array}{l}\text { Average simulated } \\
\text { discharge }\left(\mathrm{m}^{3} / \mathrm{s}\right)\end{array}$ & $\begin{array}{l}\text { Average measured } \\
\text { discharge }\left(\mathrm{m}^{3} / \mathrm{s}\right)\end{array}$ & $\begin{array}{l}\text { Difference average } \\
\text { measured discharge and } \\
\text { Simulated Discharge }\left(\mathrm{m}^{3} / \mathrm{s}\right)\end{array}$ & $\begin{array}{l}\text { Percent difference } \\
\text { simulated discharge }\end{array}$ \\
\hline $\mathrm{Rh}=0.4596$ & 0.5704233 & 0.498962 & 0.0732 & 0 \\
$\mathrm{Rh} \times 1.2=0.5512$ & 0.69474212 & 0.498962 & 0.19564 & $21.82 \%$ \\
$\mathrm{Rh} \times 0.7=0.3223$ & 0.30842516 & 0.498962 & 0.1926 & $-46.02 \%$ \\
\hline
\end{tabular}

Table 7: Difference measured discharge and simulated discharge with difference information input wind speed

\begin{tabular}{lllll}
\hline $\begin{array}{l}\text { Average wind } \\
\text { speed }(\mathrm{m} / \mathrm{s})\end{array}$ & $\begin{array}{l}\text { Average simulated } \\
\text { discharge }\left(\mathrm{m}^{3} / \mathrm{s}\right)\end{array}$ & $\begin{array}{l}\text { Average measured } \\
\text { discharge }\left(\mathrm{m}^{3} / \mathrm{s}\right)\end{array}$ & $\begin{array}{l}\text { Difference average } \\
\text { measured discharge and } \\
\text { simulated discharge }\left(\mathrm{m}^{3} / \mathrm{s}\right)\end{array}$ & $\begin{array}{l}\text { Percent variable } \\
\text { simulated discharge }\end{array}$ \\
\hline Wind $\times 0.73=1.79$ & 1.2898396 & 0.498953716 & 0.7923 & $127.15 \%$ \\
Wind $\times 1.6=3.86$ & 1.23933723 & 0.498953716 & 0.7423 & $119.33 \%$ \\
Wind $=2.56$ & 0.5704233 & 0.498953716 & 0.0720 & 0 \\
\hline
\end{tabular}

Table 8: Difference simulated discharge with difference information input temperature

\begin{tabular}{lllll}
\hline & $\begin{array}{l}\text { Average simulated } \\
\text { discharge }\left(\mathrm{m}^{3} / \mathrm{s}\right)\end{array}$ & $\begin{array}{l}\text { Average measured } \\
\text { discharge }\left(\mathrm{m}^{3} / \mathrm{s}\right)\end{array}$ & $\begin{array}{l}\text { Difference average } \\
\text { measured discharge and } \\
\text { simulated discharge }\left(\mathrm{m}^{3} / \mathrm{s}\right)\end{array}$ & $\begin{array}{l}\text { Percent variable } \\
\text { simulated discharge }\end{array}$ \\
\hline $\mathrm{T} \times 0.67=7.7627383$ & 0.79410479 & 0.498953716 & 0.2963 & $39.29 \%$ \\
$\mathrm{~T} \times 1.53=16.635586$ & 0.242062693 & 0.498953716 & 0.2572 & $-57.63 \%$ \\
$\mathrm{~T}=11.08966$ & 0.5704233 & 0.498953716 & 0.0723 & 0 \\
\hline
\end{tabular}

Table 8 shows variance simulated discharge with alteration data input temperature and temperature is increased then discharge is decreased and temperature is decreased then discharge is increased.

\section{Wind Speed}

With a $52 \%$ rise and a $33 \%$ decline in input wind speed, the obtained average monthly runoff would be 1.34 and 1.36 cubic meters per second. The simulated standards are 0.76 and 0.82 higher than the observed average monthly runoff (Fig. 14 and 15, Table 7).

\section{Temperature}

With a $53 \%$ rise and a $33 \%$ decline in the input temperature, the average monthly runoff diversed from 0.5704233 to 0.242062699 and 0.79410473 , that is, a $57.63 \%$ rise and a $39.32 \%$ decline in the monthly runoff. The Simulated consequences are $53 \%$ minor and $62.03 \%$ higher than the Measured Average Monthly Runoff.

\section{Results}

1. With $13.52 \%$ rise in the Curve Number, the Simulated Average Monthly Runoff would $2.57 \%$ adjacent to the measured average runoff. With a $1.53 \%$ rise in the roughness factor of watershed, the Simulated runoff define $0.012 \%$ closer to the Measured Discharge

2. SWAT software is a good tool to estimate Average Monthly runoff using the precipitation, temperature and other required data. A $33 \%$ decline in the average monthly precipitation, solar radiation, relative humidity, wind and temperature would origin a $64.33 \%$ decline, $114.79 \%$ rise, $46.02 \%$ decline, $126.23 \%$ rise and $39.36 \%$ rise, individually. It is apparent that the precipitation and the relative humidity face the greatest declines. The greatest intensification in runoff was a purpose of wind, then solar radiation and lastly temperature

3. With a $53 \%$ rise in the Average Monthly precipitation, a $22 \%$ rise in the radiation and relative humidity and a 53\% rise in wind and temperature, the quantity of displayed runoff would face a $125.46 \%$ increase, $3.9098 \%$ increase, $21.89 \%$ increase, $117.33 \%$ increase and $57.64 \%$ decline, individually. Precipitation then wind and relative humidity origin the greatest intensifications. The least runoff sensitivity is related to the solar radiation 


\section{Acknowledgment}

This research was supported by the Isfahan University of the Technology. We thank our all authors who provided insight and expertise that greatly assisted the research.

\section{Author's Contributions}

All authors contributed to design the study, write and revise the manuscript.

\section{Ethics}

The present Study and ethical aspect were approved by the Isfahan University of the Technology. The present study was approved by the Isfahan University of Technology.

\section{References}

Akram, M. S., Mirza, K., Zeeshan, M., Ali, M., \& Ahmed, L. (2018). Geotechnical Investigation and Prediction of Rock Burst, Squeezing with Remediation Design by Numerical Analyses along Headrace Tunnel in Swat Valley, Khyber Pakhtunkhwa, Pakistan. Open Journal of Geology, 8(10), 965-986

Chu, T. W., \& Shirmohammadi, A. (2004). Evaluation of the SWAT model's hydrology component in the piedmont physiographic region of Maryland. Transactions of the ASAE, 47(4), 1057.

Ghane, M., \& Alvankar, S. R. (2015). Sensitivity Analysis of Meteorological Parameters in Runoff Modelling Using SWAT (Case Study: Kasillian Watershed). Journal of Water Sciences Research, 7(1), 63-78.

Ghane, M., Alvankar, S. R., Eslamian, S., Ostad-AliAskari, K., Gandomkar, A., Dehghan, S., ... \& Dalezios, N. (2017a). A study on the effects of earth surface and metrological parameters on river discharge modeling using swat model, case study: kasillian basin, mazandaran province, Iran. Intl J Const Res Civ Eng, 3, 99-120.

Ghane, M., Alvankar, S. R., Eslamian, S., AmoushahiKhouzani, M., Gandomkar, A., Zamani, E., ... \& Singh, V. P. (2017b). Sensitivity analysis of runoff model by swat to meteorological parameters: a case study of kasillian watershed, mazandaran, Iran. Int J Res Stu Agri Sci, 3, 1-20.

Ghane, M., Singh, V. P., Ostad-Ali-Askari, K., \& Dalezios, N. R. (2018). Simulation of Hydrology in Ungauged Watersheds: SWAT Modeling in Kasillian Basin in Iran.

Gholami, S. H. (2003). The simulation of daily sediment yield by using distributed SWAT model in mountainous catchments (Amameh Catchments).
Hao, F. B., Zhang, X. S., \& Yang, Z. F. (2004). A distributed non-point source pollution model: calibration and validation in the Yellow River Basin. Journal of Environmental Sciences, 16(4), 646-650.

Lei, Y., Zhonggen, W., \& Shengjun, C. (2015). Study on Real Water-Saving in Agricultural Region Based on Improved SWAT Model. Physical and Numerical Simulation of Geotechnical Engineering, (20), 59.

Mwendera, E. J., \& Feyen, J. (1992). Estimation of depression storage and Manning's resistance coefficient from random roughness measurements. Geoderma, 52(3-4), 235-250.

Ostad-Ali-Askari, K., Dehghan, S., \& Ghane, M. (2020). Sensitivity Analysis of Runoff Model by SWAT. LAP Lambert Academic Publishing. ISBN10: 6200549621, ISBN-13: 978-6200549624.

Omani, N., Tajrishy, M., \& Abrishamchie, A. (2007). Streamflow simulation using of SWAT and GIS model. Seventh International Seminar Of River Engineering, Shahid Chamran University Of Ahvaz (In Persian).

Rallison, R. E., \& Miller, N. (1982). Past, present and future SCS runoff procedure. In Rainfall-runoff relationship/proceedings, International Symposium on Rainfall-Runoff Modeling held May 18-21, 1981 at Mississippi State University, Mississippi State, Mississippi, USA/edited by VP Singh. Littleton, Colo.: Water Resources Publications.

Rostamian, R., Mousavi, S., Heidarpour, M., Afyuni, M., \& Abaspour, K. (2006). Apllication Of SWAT 2000 Model For Estimating Runoff and Sediment In Beheshtabad, Sub-basin Of Northern Karun. A Thesis Presented for a Degree Master of Science (M. Sc) in Geology, Faculty Of Agriculture.

Saadati, H. (2003). Effect Of Land Use On Simulating Daily Discharge Flow Using SWAT Mathematical Model (Case Study: Kasilian Catchment Area). A thesis presented for the degree of Master in Watershed Management. Tarbiat Modares University. Natural Science Faculty (in persian).

Santhi, C., Arnold, J. G., Williams, J. R., Dugas, W. A., Srinivasan, R., \& Hauck, L. M. (2001). Validation of the swat model on a large rwer basin with point and nonpoint sources 1. JAWRA Journal of the American Water Resources Association, 37(5), 1169-1188.

Schuol, J., Abbaspour, K. C., Srinivasan, R., \& Yang, H. (2008). Estimation of freshwater availability in the West African sub-continent using the SWAT hydrologic model. Journal of hydrology, 352(1-2), 30-49.

Soil Conservation Service. (1972). National engineering handbook, section 4, hydrology.

US Department of Agriculture. (1986). Technical release 55: Urban hydrology for small watersheds. 